\title{
USING GRAPHIC ORGANIZER AS A MEDIA IN STUDENTS' WRITING PROJECT
}

\author{
Anastasia Dewi Anggraeni; Helda Jolanda \\ Pentury
}

\begin{abstract}
Program of English Education, Faculty of Language and Art, University of Indraprasta PGRI Jalan Nangka No. 58C Tanjung Barat, Jagakarsa, South Jakarta 12530 angelinanasta@gmail.com, jolandapentury69@gmail.com@yahoo.com
\end{abstract}

\begin{abstract}
Picture tells a thousand words. It is important that teachers help the students to organize their writing which are learnt to build and enhance their writing skill. Graphic organizer is a great creative media for comparing and contrasting text or story and will be used easily in every kind of topic to help the pupils know the various distinctions between the texts or stories. Beside that aim, graphic organizer also helps the students to organize their writing skill and enhance their writing skill well. Graphic organizer is considered to enhance student's writing skill, also expresses the students creativity by using all kind of texts, images and graphics, so the research hyad the observation and carried by descriptive research method. By implementing the strategy of using graphic organizer in students's writing project, teachers will hopefully get the insight of using creative media to enhance students ${ }^{\text {ee }}$ writing skill.
\end{abstract}

Key words: graphic organizers, media, writing

\begin{abstract}
ABSTRAK
Gambar menceritakan segalanya. Hal penting bahwa guru dapat membantu para siswanya dalam menyusun penulisan yang dipelajari mereka untuk membangun dan mengembangkan ketrampilan menulis mereka. Graphic organizer adalah media kreatif yang hebat untuk mengkontraskan dan membandingkan teks atau cerita dan dapat dengan mudah diterapkan dalam berbagai topik untuk membantu mereka memahami perbedaan dalam teks atau cerita. Selain tujuan tersebut, media ini pun membantu para siswa menyusun dengan baik teks atau cerita dengan baik. Graphic organizer dipertimbangkan sebagai salah satu media dalam mengembangkan penulisan siswa, karena para siswa dapat menungkapkan kreatifitas menulis mereka dengan menggunakan teks, gambar maupun grafik. Oleh sebab itu penelitian ini menggunakan metode pengamatan dan metode deskriptif. Dengan menerapkan penggunaan media graphic organizer dalam proyek penulisan siswa, guru diharapkan mendapat pemahaman yang baik dengan menggunakan media yang kreatif dalam mengembangkan keterampilan menulis siswa.
\end{abstract}

Kata kunci: graphic organizers, media, menulis 


\section{INTRODUCTION}

Choice of topic and activity is at the heart of writing lessons, more so the suitable great media is needed to support the activity and also the method. In some activities we need to supply different method, strategy, media or variations on the activity to dig the creativity of the students' idea to write.

Writing skill as one of skills that needs to be improved and practiced. Through writing the students can express their ideas and thoughts into written form. The ability of the teachers in motivating and encouraging the students to be familiar and do more practice in writing are very needed in enhace their writing skilll. Methodology in Language Teaching are four steps of basic writing, they are; planning, drafting, revising, and editing (Richards, 2002).

Planning (pre-writing) is a learning process in the classroom that enhance students' writing skill. It helps thoughts to grow well. The learning experiences include group brainstorming, clustering, rapid free writing, Whquestions. Some difficult things in writing activity, as giving an easy brainstorm, identify the idea, or how to organize the idea and the concept, are some ways of writing process which is encourage us as the teacher to design it well for the students.

Some difficult things in writing process, such as giving an easy brainstorm, identify the idea, or how to organize the idea and the concept, are some ways of writing process which is encourage us as the teacher to design it well for the students.

When the teachers ask them to do the materials for the writing project, they usually stuck in the traditional way of teacher'textbook. The students are difficult to understand the text pattern, the idea by using the vocabularies and the concept of how to make the whole ideas to be more sense from explicit or implicit ideas. They are faced of the conclusive question of the core implication from the text or the content.

The students also faced the fact of some challenges in comprehending and organizing information from the text. Based on some challenges students faced above, this is where the graphic organizer comes to solve the problems. A Graphic Organizer (GO) is quite a creative media expresses the text concepts. It is an instructional tool that can help students to organize, structured the information and concepts to relate with the other concepts. In addition, the spatial arrangement of GOs allows the students to identify the missing information or absent connections in one's strategic thinking (Zaini, Mokhtar, \& Nawawi, 2010). A simple and widespread definition is that GOs are "visual representation of information in the text" (Jiang \& Grabe in Manoli, 2012:34).

Graphic organizers have been sorted into four categories according to the interrelatedness of information to be presented in a particular graphic organizer (Ermis, Struble in Condidorio (2010). These categories include conceptual, hierarchical, cyclical, and sequential.

In short, graphic organizer presents concept of text, graphics, graph visually help students to understand the concept, using their creativity to express their ideas of the information which they got from the text easily. They use graphic organizer in visual display with the various types of graphic organizer to organize the information of the text differently based on the type of the graphic organizer and the topic of the text. The aimed to do this research so that the students can get great advantages by 
using graphic organizers. They are: 1 . The students are challenging to express their creativity. 2. They like to write creatively by using images and graph.3. graphic organizers help them to enhance and enrich their various ways to write.4. They are having fun to do and enhance their imaginative process.

There are several types of graphic organizer. Some examples include cognitive maps, story map, venn diagrams, semantic map, concept map (Manoli, 2012).

According to literature, a variety of terms is used to refer to GOs, such as visual displays, graphic (al) displays/representations, graphics, tree diagrams, structured over-views, network representations, adjunct displays/aids to name some of the most common (Manoli, 2012).

Using the media of graphic organizers to enhance students writing skill in their writing projects are enrich their ideas to create kinds of type of text creativily. Graphic organizers also increase the comprehension of text pattern. They guide the students to demonstrate the students' thinking process, easy to identify and classify the information as well.

There are a lot of definitions of media. According to Smaldino, Lowther, and Russell in Mantiri (2014), media, the plural form of medium, are means of communication. In addition, they state that media are anything that carries information between a source and a receiver. It means that in teaching and learning process, teachers can explain the materials using the learning media in a more concrete way.

Media are various components in learners' environment which support the learners learn (Wanarti, et. al., 2016) Briggs in Asyhar, 2012 argues that the media are as the physical things which are used to send messages to students as stimulation for them. A little beat differences from the opinions of the two experts, The National Education Association defines that media are the forms of communication either printed or audiovisual.

There are various kinds of media, but visual aids are the appropriate media for learners, particularly young learners. The visual aids which are commonly used for teaching English are pictures, really or real objects, drawings or teacher-made drawings charts, posters, cartoons, and flash cards. Whatever the definitions of media are, there is a guideline which can be stated about media. Media is anything used to send message(s) from the sender(s) to the receiver(s), so it can be aroused the learners' thought, feeling, and interest to gear the students' learning (Sadiman, dkk., 2011).

Mass media consists of the various means by which information reaches large numbers of people, such as television, radio, movies, newspapers, and the Internet. Print media help us to motivate students by bringing a slice of real life into the classroom and by presenting language in its more complete communicative context (Mansoor \& Saeedeh, 2013). Media can also provide a density of information and richness of cultural input not otherwise possible in the classroom, they can help students process information and free the teacher from excessive explanation, and they can provide contextualization and a solid point of departure for classroom activities. The following statements summarize the rational for using media in the language classroom (Mansoor \& Saeedeh, 2013):

1) Given the role media play in the world outside the classroom, students expect to find media inside the 
classroom as well. Media thus serve as an important motivator in the language teaching process.

2) Media materials can lend authenticity to the classroom situation, reinforcing for students the direct relation between the language classroom and the outside world.

3) Since the learning styles of students differ (Oxford, 1990; Reid, 1987; Skehan, 1980; Wenden \& Rubin, 1987), media provide us with a way of addressing the needs of both visual and auditory learners.

4) The role that input plays in language learning is virtually uncontested (Krashen in Mansoor \& Saeedeh, 2013). By bringing media into the classroom, teachers can expose their students to multiple input sources. Thus, while decreasing the risk of the students ' becoming dependent on their teacher's dialect or idiolect, they can also enrich their language learning experiences.

5) With references to schema theory (Schank \& Abelson in Mansoor \& Saeedeh, 2013), which proposes that we approach new information by scanning our memory banks for related knowledge, media can help students call up existing schemata and therefore maximize their use of prior background knowledge in the language learning process.

The definitions of writing are variously stated by some experts. According to Elbow in Brown (2001) also says that writing is a two-step process. He also claimed that writing is a thinking process. Furthermore, he states that writing can be planned and given with an unlimited number of revisions before its release.

The first process is figuring out the meaning and the second process is putting the meaning into language.
Writing represents what we think. It is because the writing process reflects things, which stay in the mind. Students who are reluctant to write things down often suffer for this activity. The students find difficulties when they start looking for some reasons to write and producing written sentences.

Another definition of writing skill is also defined by Urquhart and Mclver and also Harmer. Urquhart and Mclver state that writing is a recursive process, which means students revise throughout the process, frequently moving back and forth among the stages (Ariyanti \& Qomar, 2016). Then, students should learn strategies for invention and discovery, and teachers should help students generate content and discover a purpose. Also, it is stated that readers, purpose, and occasion define all types of writing and effective writing fulfills the writer's intention and meets the readers' needs. It means that writing is a complex process and it seems reasonable to expect, then, that the teaching of writing is complex as well. Moreover, Harmer in Ariyanti \& Qomar (2016) states that writing encourages students to focus on accurate language use. It is because students consider the language use when the students engage in their writing process. This activity will provoke language development because the students resolve problems what writing puts in students' minds.

Based on the definitions above, writing is a productive process done through some stages. Firstly, exploring and transmitting ideas, thought and feeling into written form. Secondly, conducting a number of revising process to carry out a grammatically and orderly texts. The writing productions are in the forms of readable texts which should be meaningful to everyone who read the writing. 
Types of writing activities to perform writing should be based on the students' level and capacity. There are five major categories of classroom writing performance as affirmed by Brown (2001) as follows:

1) Imitative, or writing down This type is at the beginning level of learning to write. Students will simply write down English letter, words, and possibly sentences in order to learn the conventions of the orthographic code.

2) Intensive, or controlled This intensive writing typically appears in controlled, written grammar exercises. This type of writing does not allow much creativity on the part of the writer. A controlled writing is to present in which the students have to alter a given structure through out.

3) Self-writing The most salient instance of this category in classroom is notetaking by the students. Diary or journal writing also falls into this category.

4) Display writing For all language students, short answer exercises, essay examinations and research reports will involve an element of display. One of the academic skills of ESL students that they need to master is a whole array of display writing techniques.

5) Real Writing Some classroom writing aims at the genuine communication of messages to an audience in need of those messages.

\section{METHOD}

This research is conducted qualitative method descriptively. Descriptive research, according to Gay (2000) and Airasian (2000) is a discipline in determining and describing the way things are. This study used classroom action research by observing the students' writing projects. Having writing tests using Graphic organizer is also shown by the students in writing tests process. The subject and object of research is taken through the writing projects. The entire data are taken from 65 respondents from two classes. The respondents are the students from English Education Department of Indraprasta PGRI University in third semester for samples.

\section{RESULTS AND DISCUSSION}

Based on the results of observations were have done by the author, the various types of graphic organizers are used in the students's writing projects creativily and different point of view. They have experienced a basic writing lesson in various activities. The students enhanced the selecting graphics, the graph relevant with the content or the text.

Here is the table which is describe students'projects using graphic organizers.

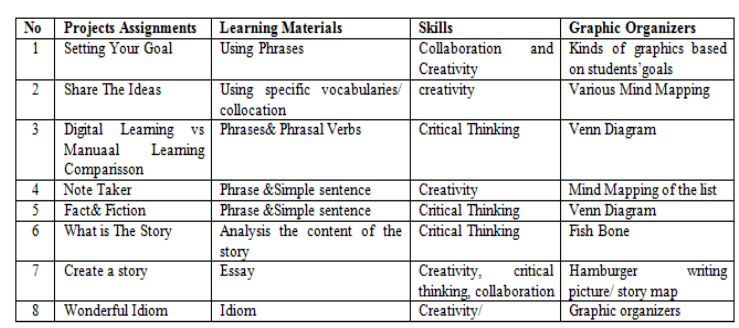

Table 1.

Student's Project Using Graphic Organizers

The Activities of the learning writing skill can create some amazing skills from the students, such as creativity, how students use the media of graphic organizers to design and develop their ideas using kinds of graphis. Beside that, students use multiple resources to plan, design, and decide the graphics based on the ideas they have. Here is the example of how 
students develop their ideas using graphic organizers:

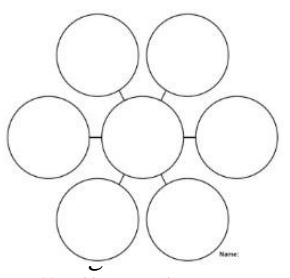

Source: https://callowayhouse.com/freeprintables/graphic-organizers/

The picture above describes students develop their ideas and knows how to relate the ideas of their setting goal plan with the concept of the goals. Picture describes students project of sharing their ideas. Using the graphic organizers helps them to lear the phrases andalso the collocation eaasily and creativily. They use various kinds of graphic design as interesting as they feel.

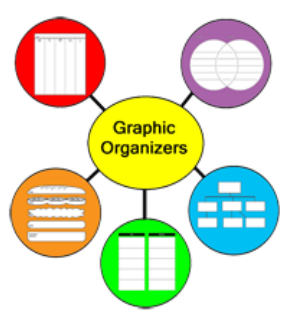

Figure 2

Source:http://edutech4teachers.edublogs.org/2013/09/2 5/graphic-organizers/

Students also apply critical thinking by identify the similar and the difference based on the topic of the projects given. They organize the finding of the topic by putting the things which are similar and the things which are different. Here is the picture of venn diagram to show the project.

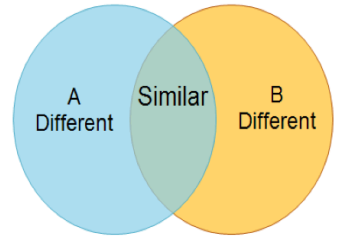

Figure 3
Source: https://ldaamerica.org/graphic-organizers/

Creating a story needs a comprehension to plan the outline first and later to write a good story. So, the creative media is needed to develop their creative mind to dig and pour it into the creative story. Here is one of the graphic organizer used by the students to create their writing project, shown in figure. 4

\section{Hamburser Writins}

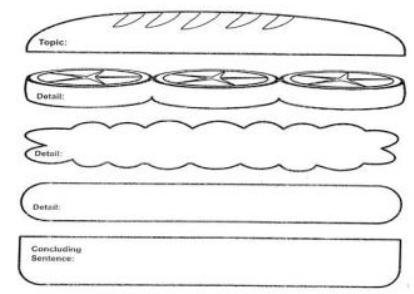

Source:https://id.pinterest.com/pin/5654129282021806 98/?autologin=true

Based on the table and the picture samples above, it can be concluded that students ' writing projects are effective use to teach the students to write well. The graphic organizer specificallyenables media that facilitates collaborative the lesson, expand the students' ideas and their critical thinking.

\section{CONCLUSION}

For our students, learning writing skill can be amazing experience, it can't be monotonous routine. The projects implemented in a fun, creative and meaningful way. Teachers can use many various graphic organizers to explain the learning material effectively. 
Using words, phrases, and sentences about the projects and illustrate them in graphic organizer are interesting and understandable well. The teachers assigned the projects creatively to dig the students creativity are really great pedagogical learning process.

\section{REFERENCES}

Airasian, L. G. (2000). Educational Research Competencies for Analysis and Application (Vol. Six Editions). New Jersey: Prentice Hall.

Ariyanti, S., \& Qomar, A. H. (2016). The Correlation between Students' Reading Motivation, Vocabulary Mastery and Writing Ability in Recount Text. Premise Journal , 5(2), 21-32.

Asyhar, R. (2012). Kreatif Mengembangkan Media Pembelajaran. Jakarta: Gaung Persada (GP) Press.

Brown, H. D. (2001). How to Teach English. England: Pearson Education Limited.

Condidorio, K. (2010). The Usefulness of Graphic Organizers in Enhancing Science Learning. Education Masters Paper 111.

Gay, L. R. (2000). Educational Research: Competencies for Analysis and Application. New Jersey: Pretince-Hall, Inc.

Manoli, P. (2012). Graphic Organizers as a Reading Strategy: Research Findings and Issues. Creative Education, 3(3), 348-356. https://doi.org/10.4236/ce.2012.330 55

Mansoor, T., \& Saeedeh, E. (2013). The Effect of Using Print Media on Children's L2 Literacy Development: A Longitudinal
Study. Journal of Language Teaching and Research, 4(3), 570578.

https://doi.org/10.4304/jltr.4.3.570578

Mantiri, F. (2014). Multimedia and Technology in Learning. Universal Journal of Educational Research, 2(9), 589-592. https://doi.org/10.13189/ujer.2014.0 20901

Richards, J. (2002). Methodology in Language Teaching: An Anthology of Current Practice. UK: Cambridge University Press.

Sadiman, dkk. (2011). Media Pendidikan: Pengertian, Pengembangan dan Pemanfaatannya. Jakarta: Raja Grafindo Persada.

Wanarti, et. al. (2016). The Enhancement of Teaching-Learning Process Effectiveness through. Advances in Economics, Business and Management Research, 14, 343.

Zaini, S. H., Mokhtar, S. Z., \& Nawawi, M. (2010). The Effect of Graphic Organizer on Students ' Learning in School. Malaysian Journal of Educational Technology, 10(1), 1723. 